\title{
MANAGEMENT WITH APPLICATION OF THE FINANCIAL ANALYSIS IN THE FOOD INDUSTRY IN SLOVAKIA
}

\author{
Milan Majernik, Stefan Majernik, Miroslav Rusko, Jan Ilko, \\ Vojtech Kollar \& Ruzena Kralikova
}
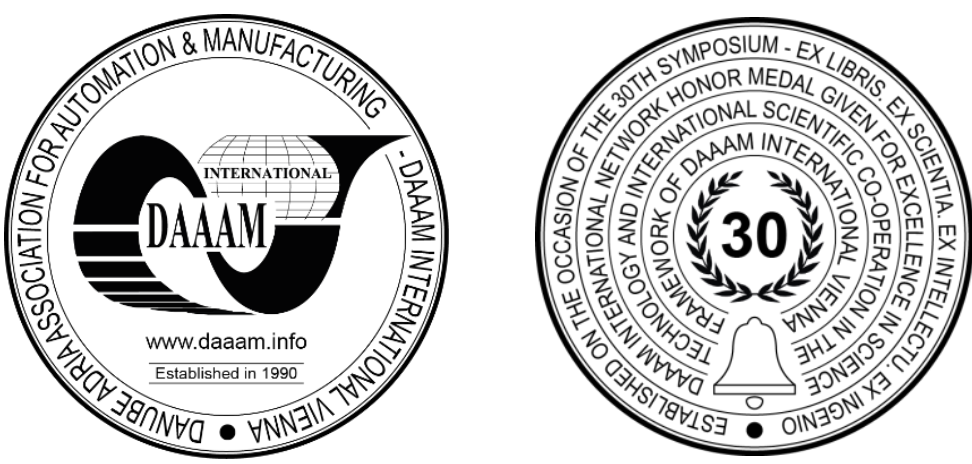

This Publication has to be referred as: Majernik, M[ilan]; Majerník, S[tefan]; Rusko, M[iroslav]; Ilko, J[an]; Kollar, V[ojtech] \& Kralikova, R[uzena] (2020). Management with Application of Financial Analysis in the Food Industry in Slovakia, Proceedings of the 31st DAAAM International Symposium, pp.0348-0355, B. Katalinic (Ed.), Published by DAAAM International, ISBN 978-3-902734-29-7, ISSN 1726-9679, Vienna, Austria

DOI: $10.2507 / 31$ st.daaam.proceedings.049

\begin{abstract}
This contribution deals with a financial analysis and financial resources of the European Union in a selected company. For food industry, it is now very much topical, for the sake of market stability and competitiveness, to use the available Euro-funds to the maximum possible extent in 2014-2020 [1]. Regarding the new priorities of the European Union, new conditions of the international market and the new competition, it is essential for companies in each sector to know their financial structure. It is the financial situation that provides an over-all characteristic of the company, which enables to correctly select resources to finance needs, and to allocate the obtained resources to particular items of the property. Optimization of the financial structure in food industry companies should bring a new view of a rational composition of company's equity and liabilities. For the company, the financial analysis is currently an important measure, as it has been applying for a non-returnable financial assistance from the Rural Development Programme of the Slovak Republic for 2014-2020. One part of the application requires proving the satisfaction of the economic viability criteria, and financial analysis is the tool which can either confirm or rebut this viability.
\end{abstract}

Keywords: Food industry; Financial analysis; Management; European Union; Invention; Business results.

\section{Introduction}

On May 1, 2004, Slovakia became part of the unified market of the European Union (EU), which by its size, population and economic strength ranks among the largest groupings of the world [2]. The integration of Slovakia into the EU puts tasks for business management related to the analysis of the external environment, identifying critical strengths and weaknesses, addressing the challenges of adapting to European standards and exploiting opportunities in the wider market space. [14], [15] The European market requires increased costs of implementing EU directives and regulations in the production of individual products. It is a matter of respecting EU hygiene regulations and good manufacturing practice so that the production process and the end product are expected to be accepted both on the domestic market and on the overall EU market [3]. 
The new European food law defines a food safety and health system as a system that starts with primary agricultural production and ends on the consumer's desk. The system encompasses all stages of production, storage, distribution and offers to sell both food and food chain inputs. In particular, the basic principles and rules of good manufacturing and hygiene practice, traceability of the raw material to the final product for all phases and stages of the food chain are taken into account.[12], [13] According to this principle, businesses must be able to show who they bought used inputs and to whom they sold their products - simply the rule of proving "one step forward and one step back" applies.

The analytical activity is multifaceted and diverse, involving the knowledge of complex phenomena and processes that take place in a rapidly changing market economic environment. [16] The analysis constitutes a tool for examining and evaluating these processes, in particular the conditions under which they take place, as well as for examining the effects and causal relationships that operate there. [17]

Application of the analysis in the enterprise includes both economic and technical areas, which form a compact whole. Therefore, an effective way of financial analysis of business finance presupposes a creative and differentiated approach based on specific conditions and objectives pursued. It must seek and find an answer to economic events and be able to respond correctly to movements in the microeconomic and macroeconomic environment and thus to achieve fundamental changes in business performance.

\section{Analysis of the financial situation of the company}

The financial situation of the company systematically and comprehensively reflects the quality of business activities, its economic level and is therefore a good starting point and a means of diagnosing the strengths and weaknesses of business activities [4]. They are both the internal context of financial analysis, but equally important are the external context of financial analysis. Through its financial situation, the company presents itself to its market partners, on the basis of which the conditions for business relationships are evaluated and determined. Indeed, the financial situation of an enterprise provides an overall characteristic of the enterprise that allows for the sound financing of the company's business, i. to choose the right sources of financing for needs and to place the obtained resources in individual components of assets.

The main issues of financial analysis and the level of crucial business activities to define the core issues of financial analysis, it must be emphasized that a market economy requires the application of new methods in business management, market conditions and needs. Economic analysis is a resource up-to-date, objective and comprehensive information for top management. The change of position and tasks of economic analysis finds its expression in changes of content, organization and methodological. The analysis must provide sufficient information for strategic and operational management of the company to the market orientation of the company. Market orientation finds its manifestation in its summary results, which provides analysis of the financial situation of the company. In the recent past, financial analysis was only a pendant of economic analysis and its main task was to control the fulfilment of the company's obligation to the state budget.

In market conditions, financial analysis forms the starting point for knowing aggregate results that are reflected in the financial situation of the company. This reflects the economic success and level of production, innovation, commercial and other activities of the company, which are crucial for further economic development of the company. At the same time, the analysis focuses on partial results, which enable precision of results also from a technical and economic point of view. This approach perceives the link between technology and economics in ongoing processes and their quantification in value.

It should be noted that even today the definition and content of the financial and economic analysis narrow in the direction of financial control. It is based on the position of the passive register of what has happened and can no longer be changed, ie the state is stated. From our conception, the financial-economic analysis must be transformed into a very active influence on the management process, which is a source of comprehensive information for the decision-making process. Financial analysis is based on a retrospective, whose task is to explain the current situation, to analyze the existing financial situation by looking into the past. Its main task is to identify determinants, their character, i. whether they act as an accelerator or a retardant. However, this cannot be changed.

\section{Key issues of financial analysis}

The key issues of financial analysis include:

- Analysis of company liquidity.

- Analysis of the financial structure of the company.

- Business activity analysis.

- Analysis of company profitability.

- Analysis of market value of the company [5].

Liquidity analysis is aimed at assessing the ability of an enterprise to meet its obligations. This ability is determined primarily by the structure of assets having different liquidity, i. liquidity or the speed at which individual items of current assets are converted into cash. 
The issue of liquidity is often underestimated, since the focus of most businessesis on profit and profitability. However, this is not sufficient, as showing a profit in the financial statements does not mean having no payment problems. This implies that liquidity and profit developments may be diametrically opposed. Analysis of the financial structure is focused on the examination and assessment of financial resources of the company and influencing their rational composition. Adequate proportions of own and external resources testify to a good corporate economy and at the same time affect the business and credit credibility of the enterprise.

The analysis of the company activity is focused on the research of the efficiency as an efficient enterprise manages its assets. The relation of assets and individual components to the achieved effects - performance is assessed. Specifically, it is an analysis of turnover, efficiency of corporate assets as a whole. The analysis of the profitability of the company practically represents an analysis of the liabilities of the balance sheet and represents a certain synthesis of the previous three analyzes, the results of which are reflected in the profitability and give a comprehensive view of the business activity. A common feature of all business entities is the desire to maximize profit, but it should be stressed that maximizing profit cannot be understood as maximizing the return on total capital, but only as maximizing the return on equity.

The market value analysis of an undertaking forms part of a financial analysis in which the view of market-based entities interested in the market value of the undertaking is applied. This interest is motivated by the effort to effectively invest free financial resources. To reflect this, financial indicators working with inputs that are generated on the financial market, such as the market price of shares, are used. Its explanatory power is closely linked to the fundamental questions of financial analysis. The acquired knowledge suggests that financial analysis represents the first steps to know the basic indicators of the financial situation of a company. It is developed by oriented diagnostics with an effort to predict the development of the company's financial and economic situation. It is preferable that the company management can anticipate the development and correct the negative tendencies in time. The diagnosis of the position of the company and the questions of the development of the company give new meaning to the targeted financial analysis.

The explanatory power of financial analysis must be seen in the fact that it is an effective means of evaluating a company. On the basis of basic data from the financial statements is constructed a system of ratio and difference indicators, which allows a comprehensive view of the objective financial situation of the company. Knowledge of strengths and weaknesses helps managers to improve the process of deciding on the future direction of the company. The practical application of financial analysis is oriented in this respect with a focus on two parts. It is based on desirable theoretical knowledge from the business economy and from the concept of financial-economic analysis of the company as a basis for decision-making process. It is an approach to analysis as a diagnostic tool that provides business management with critical information.

Its concept is based on a retrospective, which includes the first part of the work with the task of identifying determinants and their character. It is about assessing whether they act as an accelerator or a retarder, that is to say an 'expost' analysis. The second part is devoted to the perspective oriented analysis with an effort to predict the development of the financial and economic situation of the company. It is preferable that business management is able to anticipate the development and to correct negative tendencies before they develop into undesirable failures until the financial collapse of the business. It is an ex-ante-oriented analysis of the future. The pragmatic aspect of financial analysis is applicable to the food industry.

\section{Objective and methodology}

The aim of the paper is to evaluate management with the use of financial analysis in the food business with the output for innovative knowledge, partial and synthetic knowledge for practice. Using the methods of financial analysis, a company can quantify the values of important indicators. Based on this data and knowledge, the company can assess its financial situation and focus on solving problem states.

The methodology of work processing is based on general methods of knowledge, logical thinking and application of analytical - synthetic method and inductive - deductive method. The comparative method is widely used as a working method of analysis, which shows how management and economic processes assert themselves in specific time conditions, assuming the quantifiability of the compared values. Furthermore, some more accessible mathematical and statistical means of expression are used.

\section{Results and discussion}

\subsection{Innovative knowledge of management and financial analysis}

Management literature with the use of financial analysis under the influence of the past is often seen as a one-off act. [6]. In practice, it is a process oriented in the sense that the conclusions are broken down into individual measures, logically and chronologically connected to each other in the direction of their implementation. Problem analysis to identify causes requires a different way of thinking. We are more likely to look for analogy similarities; here, however, the revelation of difference is required. It is therefore about finding the answer to the question of what has changed, what is going on differently, since this is at the heart of the problem analysis. The key is to clearly separate the problem from what is not. 
An important new chapter has become the computer technology, which allows inform who is to decide at the time when the decision is to be taken. The benefits must be seen in the ability to process large volumes of data quickly and efficiently, opening the possibility for quality analysis based on sophisticated methods and model approaches. The systematic implementation of management and financial analysis shows the need to gradually build a financial analytical data bank, but also a bank of analysis methods.

The task is:

- Documentation security, i. creation of a system of documents, regulations ensuring the required procedures, it is about monitoring imbalances in our economy; in the financial field in particular, it is insolvency, imbalance between needs and sources of funding.

- Data security, i. creation of a system of indicators characterizing economic phenomena and processes in relation to the factual and organizational structure of management processes.

- Organizational arrangements, within the financial management unit, to create a department for financial economic analysis, in which to build up a bank of information-analytical data and a bank of methods of analysis.

- Provision of methods to improve analyzes and required outputs. It seems useful to create a bank of methods and models for the standard types of financial analysis tasks.

The problem of obtaining the necessary information is general, especially when it comes to obtaining information for intercompany comparisons. Therefore, in addition to building your own bank of information, it is necessary to establish contacts for cooperation with companies, respectively. Research institutes specialized in this Professional activity. Based on financial analysis to intensify the implementation of individual adaptation mechanisms and practically within the financial strategy of the company.

\subsection{Partial and synthetic knowledge for practice}

Based on the above, we can conclude that financial analysis and its individual indicators need in addition to the company:

- managers,

- investors,

- business partners,

- employees,

- banks and other creditors,

- the State and individual State authorities,

- analysts, tax advisors and accountants,

- competitors,

- stockbrokers, the wider public.

\section{Managers}

Managers need financial analysis and its information primarily for short and especially long-term financial management of the company. Knowledge of the financial situation of a company enables managers to take correct and decisive views, especially in obtaining financial resources, in ensuring an optimal property structure, including choosing appropriate methods of their financing, in allocating free cash, in distributing profits or paying losses and the like. It is financial analysis, which reveals the weaknesses and strengths of the company's financial management, gave business managers the opportunity to adopt the right business plan for the future, which needs to be developed primarily into the financial plan, respectively. Make the right decision.

\section{Investors}

These include, in particular, shareholders or associates of the business, owners of credit securities, potential investors [7]. Shareholders - Shareholders aim to make sure that their money is appropriately deposited and that the business is well managed, that is, the business performance of the top management is comparable to that of similar businesses. In addition, shareholders are interested in the stability and liquidity of the business for profit, on which the amount of their dividends depends, and also whether the business plans of the managers ensure the duration of the business development.

Owners of credit securities, respectively, bonds, certificates of deposit and the like - they are interested in liquidity and financial stability of the company. Their interest lies primarily in the fact that their securities will be paid to them within the set deadline and the agreed amount. Potential investors are considering their ability to place their available cash in the business and therefore need to verify that such a decision is correct.

\section{Business partners}

Business partners are primarily suppliers and customers who act as business creditors and customers [8]. Suppliers - i.e. business lenders - based on knowledge of the financial situation of potential customers, they choose their business partners. For these selected business partners, they then monitor in particular the ability to pay off liabilities and longterm stability, from which they conclude the possibility of their sales (supplies). 


\section{Customers}

They are actually customers who, like suppliers, choose their suppliers based on the results of financial analysis of individual companies. Especially in long-term contracts, customers need to make sure that the supply company is and will be able to meet its obligations.

\section{Employees}

Employees represent the category of workers who are interested in financial information, especially in terms of wages and social perspectives.

\section{Banks and other creditors}

These institutions ask the potential borrower to provide as much information as possible about their financial situation so that banks, as commercial institutions, can make the right decisions, i.e. whether they continue to lend or not lend funds to the business (granting a loan) and what their return will be. They also verify that the undertaking can offer adequate guarantees for loans (loans) and whether it will be able to make repayments under agreed conditions. As a financial institution, commercial banks very often derive their credit conditions or their changes from selected financial indicators.

\section{State and individual state authorities}

From a macroeconomic perspective, they need financial information for a number of purposes, such as statistics, tax compliance monitoring, government policy monitoring, and the like.

\section{Analysts, tax advisors and accountants}

These groups of workers are interested in the broadest possible aspects of the company's financial management so that they can identify deficiencies correctly and be able to recommend procedures to remedy them.

\section{Competitors}

Competitors are interested in financial information that is comparable to their own economic results, particularly interested in profitability indicators, profit margins and annual sales size, solvency as well as the amount and value of stocks and their turnover.

\section{Stock brokers}

This group needs to know, even on an ongoing basis, as much information as possible about the financial situation of businesses in order to be successful, especially in securities trading.

\section{The wider public}

This group of people is interested in the financial situation of the company for various reasons. One of the reasons is that it monitors whether an undertaking is not engaged in an activity contrary to environmental protection. Another reason is, for example, the fact that it takes care of the development of its region (s) and so on. Many companies achieve better indicators in favour of themselves also because they degrade the environment by their production (dust, air pollutants, etc.) and spend the least on funds to improve the environment. However, the wider public is usually interested in disclosing financial information and financial analyzes of such companies (especially large and influential) that are listed on the stock exchange and their demand is substantially more demanded.

The above-mentioned group of institutions is certainly not exhaustive. Other candidates for financial analysis and its indicators could be appointed. These include economic universities and their faculties, trade unions, economic journalists and many other workers and institutions.

\subsection{Management, financial analysis and business results}

Knowledge and experience show that the level of performance and the achievement of good business results are crucial for the quality of management, especially for internal management, based on the developed system by performing financial analysis. The rational application of financial analysis enables to direct the ongoing economic operations in the desired direction by influencing individual management decisions already during the operational management.

Financial analysis signals needs correction decisions in two forms:

- The possibility to change the course of action.

- The possibility of reducing the scope of the activity and thereby achieving cost reductions, including the possibility of losses.

The results of the financial analysis highlight the bottlenecks of the company, which find their expression in unconvincing summary results. These need to be associated with business risk, which traditionally understood as the risk of production and commercialization is now overcome, and financial risk in particular must be taken into account. Here it turns out that there is a need to deal with the less known discipline of risk management - risk management in formulating and implementing financial and business policy [9]. 
In this context, the issue of the cost and risk of corporate capital is topical in our circumstances. The results of the financial analysis confirm the generalization that the cost of equity for the enterprise is higher than the cost of foreign capital.

This is due to two main reasons:

- The risk of the owner is higher than that of the creditor. The creditor deposits the funds into the business for a predetermined period of time and is returned to it after the expiry. This return is usually secured by a guarantee. It is guaranteed a regular interest yield, which it receives regardless of the economic situation of the company.

- The owner puts funds into the business for an unlimited period of time. His income depends on the results of the company. It fully bears the business risk [10].

Interest paid on the loan is part of the business expense, reducing profit as a basis for calculating income tax. The real cost of a loan to an enterprise is not the full interest, but the interest reduced by the tax savings. If we only look at the difference in the cost of equity and foreign capital, then we can argue that increasing the proportion of foreign capital to equity interest leads to a reduction in the average cost of the total capital of the enterprise.

There are two forms of self-financing of business needs - obvious and tacit self-financing:

- Manifestly represents the retention of the part of the profits that remain after the payment of tax and dividends. The transfer of taxed profits to self-financing means a long-term increase in equity.

- Silent - hidden is created in the balance sheet by the enterprise's reserve by reducing the profit by underestimating assets or overestimating liabilities. This form of self-financing does not increase the equity shown in the balance sheet, but only the effective real capital that the company can dispose of.

The silent form of financing has the obvious advantage that the apparent reserves are created in the enterprise from taxed profits, while the silent form of self-financing does not take the form of profits and is not taxable. This form of self financing must be economically justified. A progressive approach to financial analysis sharpens the view of business performance in terms of its results, $i$. assessment of the company's profitability. It is the ability of the company to make a permanent profit in the future and thus ensure its required amount in the direction of set criteria. This expresses the core of the result-oriented analysis, which is directly dependent on the formulated yield value, i.e. the growth of the company and its financial situation.

In a market economy, the financial situation of a company has a profound impact on the creation of a corporate image with significant connections. This can be synthetically expressed in such a way that the company manifests itself through its financial situation and the environment perceives it through its financial situation [11]. A comparative view of financial analysis provides a wide and diverse range of knowledge and information. These enable their use in pedagogical practice, especially in terms of content, methodology and application in the evaluation of the results of individual production activities, innovations and other economic activities, which are reflected in the efficiency of management, in the financial flow of each business entity.

\section{Summary of the knowledge and the contribution of the financial analysis}

Business activity and its development is characterised by the need for information on the story of financial operations in the company. Everyone in this activity is faced with the problem of how to navigate the amount of information they receive, but especially how to choose those that are important to the decision-making process. It is a rational way to deal with a flood of information from the perspective of a financial manager, because it is impossible to manage without information. Management needs to understand, put it into context, analyze and draw conclusions about what needs to be done to achieve a defined purpose.

Therefore, the objective defined for the application of financial analysis is based on theoretical knowledge and their methodical application in solving substantive problems. In the pragmatic-application processing, the defined objective of the financial analysis can be considered to be achieved in a concrete confrontation of theoretical and practical knowledge.

The conclusions found in the pragmatic application of financial analysis in the food industry company give an image of:

- Performed financial analysis of the company.

- Objectifying the conclusions of the financial analysis.

- Use of financial analysis for decision-making processes of the company.

- Financial policy enterprise, ...

- Towards a proposal for action.

The findings of the financial analysis are applicable not only in the food industry but also in other sectors of the national economy, which provide us with knowledge about the level of business processes, which are mediated by financial indicators. 


\section{Objectives to continue the financial analysis}

- In the literature, financial analysis under the influence of the past is often seen as a one-off act. In practice, it is a process oriented in the sense that the conclusions are broken down into individual measures, logically and chronologically connected to each other in the direction of their implementation.

- Problem analysis to identify causes requires a different way of thinking. We are more likely to look for analogy similarities; here, however, the revelation of difference is required. It is therefore about finding the answer to the question of what has changed, what is going on differently, because it is at the heart of the problem analysis. The key is to clearly separate the problem from what is not.

- An important new chapter has become the computer technology, which allows informing who is to decide at the time when the decision is to be taken. The benefits must be seen in the ability to process large volumes of data quickly and efficiently, opening the possibility for quality analysis based on sophisticated methods and model approaches.

- The systematic implementation of management and financial analysis shows the need to gradually build a financial analytical data bank, but also a bank of analysis methods. The task is:

$\circ$ Documentation security, i.e. creation of a system of documents, regulations ensuring the required procedures, it is about monitoring imbalances in our economy; in the financial field in particular, it is insolvency, imbalance between needs and sources of funding.

- Data security, i. creation of a system of indicators characterizing economic phenomena and processes in relation to the factual and organizational structure of management processes.

- Organizational arrangements, within the financial management unit, to create a department for financial economic analysis, in which to build up a bank of information-analytical data and a bank of methods of analysis.

- Provision of methods to improve analyzes and required outputs. It seems useful to create a bank of methods and models for the standard types of financial analysis tasks.

The problem of obtaining the necessary information is general, especially when it comes to obtaining information for intercompany comparisons. Therefore, in addition to building your own bank of information, it is necessary to establish contacts for cooperation with companies, respectively. Research institutes specialized in this Professional activity. Based on financial analysis to intensify the implementation of individual adaptation mechanisms and practically within the financial strategy of the company.

\section{Future research plans}

We plan to focus further research on the application of European food law, especially on the implementation of relevant legal standards for small and medium-sized enterprises in Slovakia.

\section{Conclusion}

Finally, we consider it appropriate to indicate some remarks on the relationship between financial analysis and decision-making. In the management work we can observe that even knowledgeable analysts - managers make mistakes in this area:

- The analyst manager must know the facts, the facts, no matter how unpleasant, in the interests of good management. It must seek to know the true state of the matter, no matter where this information comes from.

- However, it should be soundly distrustful and verify the truth and accuracy of the information.

- The analyst manager should be able to distinguish facts from opinions. The fact is inseparable, it is as it is. There is no point in discussing it in the form of whether or not it is. On the other hand, the opinion can, even needs to be discussed. The loss achieved is a fact that needs to be explained and evaluated, but there is no point in discussing whether it is loss or not. It can be debated whether it is correctly reported and what to do next. The elaborated investment plan is the name and therefore it needs to be discussed.

- The magical confidence in the numbers is often surprising. It manifests itself in the pursuit of a multitude of statements with a large amount of data in which the clarity and ability to create the right picture of the matter are lost.

- It is also surprising that many decisions no longer affect the way things go. In relation to a decision, it should therefore be noted that a correct answer at the wrong time produces an inappropriate decision.

Pragmatic experience also suggests that no decision should be made unless necessary. This means that decisions are needed when and objectively requires reality. Realization of unnecessary, respectively. Early decisions increase the risk of poor decision-making. They are the result of the intellectual process of the people, resulting from their knowledge and practical experience. All managers achieve results by using the environment for effective group goals. In their work, they use a set of managerial abilities whose importance varies depending on the manager's position and organizational structure. In achieving the company's financial health, the level ofknowledge of financial analysis enables managers to maintain this financial health of the business. 
Every manager in top management must be an analyst, otherwise he / she cannot make decisions; synthesis. It is not possible to functionally divide manager - analyst and decision manager. It is an integral view as a result of financial analysis. These considerations confirm the importance of properly oriented financial analysis and its conclusions for the business decision-making process.

\section{References}

[1] Ministry of Agriculture of the Slovak republic, Agricultural Payment Agency (PPA): A guide for applicants for a non-repayable financial contribution from the Rural Development Program of the SR 2014-2020

[2] Borekova, B.: Economics of agro-industry. - Nitra: Vyd. SPU. 2004. ISBN 80-8069-306 4, 142 p.

[3] Drdak, M., Studnicky, E., Morova \& E., Karovicova, J.: Fundamentals of Food Technologies. - Bratislava: Vydavatel'stvo Malé centrum. 1996, ISBN 80-967064-1-1

[4] Majernik, M.: Financial Analysis. - Bratislava: Vyd. STU. 2001. ISBN 80-227-1514-X, 30-33 pp.

[5] Zalai, K. et al.: Financial-economic analysis of the company, practical. - Bratislava: Vydavatel'stvo Ekonóm. 2006. ISBN 80-225-2142-6, $32 \mathrm{p}$.

[6] Alexy, J. et al.: Management. - TrU, Merkantil spol. s r.o., Zlatovce 1999

[7] Danko, J. et al.: Business. - Nitra: Vydavatel'stvo SPU. 2003. ISBN 80-8069-189-4

[8] Kretter, A., Simo, D., Nagy, L. \& Vicen, M.: Marketing. - Nitra: Vydavatel'stvo SPU. 2004. ISBN 80 8069- 390-0, $288 \mathrm{p}$.

[9] Chartered Institute of Management Accountants: Management Accounting official terminology. - London: CIMA Publishing ed. 2004. ISBN 1859713475

[10] Bielik, P. et al.: Business Economics. - Nitra: Vydavatel'stvo SPU, 2002. ISBN 80-8069-069-3, 184 p.

[11] Baran, D., Palffy, A., Svitkova, M., Zatrochova, M. \& Kardos, P.: Corporate Finance. - Bratislava Vydavatel'stvo STU. 2005. ISBN 80-227-2204-9, 66 p.

[12] Akbarova, M.; Bitnyi-Shliakhto, M.; Smirnova, E. \& Popov, A.: Integrated System of Industrial Safety and Labor Protection. - Proceedings of the 30th DAAAM International Symposium, pp.0872 - 0877, B. Katalinic (Ed.), ISBN 978-3-902734-22-8, ISSN 1726 - 9679, Vienna, Austria DOI: 10.2507/30th.daaam.proceedings.121

[13] Vulanovic, S.; Zizakov, M.; Vasic, S.; Delic, M. \& Sremcev, N.: The Impact of Occupational Health and Safety $(\mathrm{OH} \& \mathrm{~S})$ Management Systems on Risk Management Practices. - Proceedings of the 30th DAAAM International Symposium, pp.1188 - 1195, B. Katalinic (Ed.), ISBN 978-3-902734-22-8, ISSN 1726 - 9679, Vienna, Austria DOI: 10.2507/30th.daaam.proceedings.167

[14] Rusko. M.; Sablik. J.; Markova. P.; Lach. M. \& Friedrich. S.: Sustainable Development, Quality Management System and Environmental Management System in Slovak Republic. - Procedia Engineering 69 (2014) $486-491$. 24th DAAAM International Symposium, 2013, doi: 10.1016/j.proeng.2014.03.016

[15] Springett, J.; Whitelaw, S. \& Dooris, M.: Sustainable development, equity and health-time to get radical, Critical Public Health, 2010, 20:3, 275-280, DOI: 10.1080/09581596.2010.502932

[16] Beske, P.; Land, A. \& Seuring, S.: Sustainable supply chain management practices and dynamic capabilities in the food industry: A critical analysis of the literature. - International Journal of Production Economics,Volume 152, 2014, Pages 131-143, ISSN 0925-5273; doi.org/10.1016/j.ijpe.2013.12.026.

[17] Bourlakis, M.; Maglaras, G.; Aktas, E.; Gallear, D. \& Fotopoulos, Ch.: Firm size and sustainable performance in food supply chains: Insights from Greek SMEs. - International Journal of Production Economics, Elsevier. Volume 152, June 2014, Pages 112-130; doi.org/10.1016/j.ijpe.2013.12.029. 